\title{
PRODUCTION OF INTERSTOCKED 'PERA' SWEET ORANGE NURSERY TREES ON 'VOLKAMER' LEMON AND 'SWINGLE' CITRUMELO ROOTSTOCKS
}

\author{
Eduardo Augusto Girardi' ${ }^{1}$ Francisco de Assis Alves Mourão Filho* \\ ${ }^{I}$ Treze de Maio, 1299 - Apto. 52 - 13400-300 - Piracicaba, SP - Brasil. \\ ${ }^{2}$ USP/ESALQ - Depto. de Produção Vegetal, C.P. 09 - 13418-900 - Piracicaba, SP - Brasil. \\ *Corresponding author<famourao@esalq.usp.br>
}

\begin{abstract}
Incompatibility among certain citrus scion and rootstock cultivars can be avoided through interstocking. 'Pera' sweet orange (Citrus sinensis L. Osbeck) nursery tree production was evaluated on 'Swingle' citrumelo (Poncirus trifoliata (L.) Raf $x$ Citrus paradisi Macf) and 'Volkamer' lemon (Citrus volkameriana Pasquale) incompatible rootstocks, using 'Valencia' and 'Hamlin' sweet oranges (Citrus sinensis L. Osbeck), 'Sunki' mandarin (Citrus sunki Hort. ex Tanaka), and 'Cleopatra' mandarin (Citrus reshni Hort. ex Tanaka) as interstocks. Citrus nursery trees interstocked with 'Pera' sweet orange on both rootstocks were used as control. 'Swingle' citrumelo led to the highest interstock bud take percentage, the greatest interstock height and rootstock diameter, as well as the highest scion and root system dry weight. Percentage of 'Pera' sweet orange dormant bud eye was greater for plants budded on 'Sunki' mandarin than those budded on 'Valencia' sweet orange. No symptoms of incompatibility were observed among any combinations of rootstocks, interstocks and scion. Production cycle can take up to 17 months with higher plant discard.
\end{abstract}

Key words: citrus, incompatibility, interstock, propagation

\section{PRODUÇÃO DE MUDAS DE LARANJA 'PÊRA' INTERENXERTADAS NOS PORTA-ENXERTOS LIMÃO 'VOLKAMERIANO' E CITRUMELO 'SWINGLE'}

\begin{abstract}
RESUMO: A incompatibilidade entre certas variedades de copa e porta-enxertos de citros pode ser evitada através da interenxertia. Avaliou-se a produção de mudas de laranja 'Pêra' (Citrus sinensis L. Osbeck) enxertada sobre os porta-enxertos incompatíveis citrumelo 'Swingle' (Poncirus trifoliata (L.) Raf $x$ Citrus paradisi Macf) e limão 'Volkameriano’ (Citrus volkameriana Pasquale), utilizando-se como interenxertos as laranjas 'Valência' e 'Hamlin' (Citrus sinensis L. Osbeck), tangerina 'Sunki' (Citrus sunki Hort. ex Tanaka) e tangerina 'Cleópatra' (Citrus reshni Hort. ex Tanaka). Mudas interenxertadas com laranja 'Pêra' sobre ambos os porta-enxertos foram usadas como testemunha. Citrumelo 'Swingle' levou à maior porcentagem de sobrevevivência de interenxertia, maior altura de interenxerto, maior diâmetro de tronco do porta-enxerto, além de acumular maior quantidade de matéria seca da copa e do sistema radicular. A percentagem de borbulhas dormentes de laranja 'Pêra' foi superior para mudas enxertadas sobre tangerina 'Sunki' quando comparadas às mesmas mudas enxertadas sobre laranja 'Valência'. Não foram observados sinais de incompatibilidade entre quaisquer combinações de porta-enxerto, interenxerto e copa. O ciclo de produção deste tipo de muda pode se estender por até 17 meses a partir da semeadura e pode haver maiores níveis de descarte de mudas ao final da produção.
\end{abstract}

Palavras-chave: citrus, incompatibilidade, interenxertia, propagação

\section{INTRODUCTION}

Interstocking is a propagation technique that avoids scion/rootstock incompatibility with no reduction in yield, even though it can result in new characteristics such as reduction in canopy size, and decrease in production per unit area (Yonemoto et al., 2004). In some fruit crops, such as apple, interstocking may lead to a direct increase in fruit yield per tree of up to $30 \%$, as well as reducing shoot growth up to $20 \%$ (Samad et al., 1999). Reduction of trunk diameter has also been observed in interstocked peaches, while flowering and fruit set increased (Scarpare Filho et al., 2000).

Most reports of interstocks in citrus show that there is no effect on fruit characteristics when using this propagation method (Sampaio, 1990), although variations in acid concentration, fruit length and peel thickness were observed in 'Verna' lemon budded on 
sour orange with different sweet orange interstocks (Llorente et al., 1984). Interstocks improved sap flow rate in lemon trees, as a result of reduction in trunk thickness at grafting point, modifying individual flavonoid content of juice (Gil-Izquierdo et al., 2004). Intertocks may not avoid virus or viroid translocation between scion and rootstock. Therefore, it could not directly affect resistance to diseases such as citrus tristeza virus (CTV) (Bitters et al., 1981). However, this technique is being evaluated in trials involving avoidance to citrus sudden death (CSD) in Brazil (Müller et al., 2002).

Poncirus trifoliata used as an interstock for 'Valencia' sweet orange on 'Rangpur' lime rootstock led to smaller plants, reduction of fruit production per tree, and fruit set delay, eight years after planting (Sampaio, 1990). Interstock length and budding height did not affect plant growth and fruit production (Sampaio, 1993). The present work evaluated the production of 'Pera' sweet orange nursery trees on incompatible 'Swingle' citrumelo and 'Volkamer' lemon rootstocks by interstocking three different citrus species.

\section{MATERIAL AND METHODS}

The experiment was carried out in a screen house at a commercial citrus nursery in Araras, SP (22²5'15" S; 47²3'03" W). 'Swingle' citrumelo 4475 (Poncirus trifoliata (L.) Raf $x$ Citrus paradisi Macf) and 'Volkamer' lemon Catânia 2 (Citrus volkameriana Pasquale) were evaluated as incompatible rootstocks for 'Pera' sweet orange (Citrus sinensis L. Osbeck) (Pompeu Jr., 1991). Four different interstocks, compatible either with 'Pera' sweet orange and both rootstocks (Agustí, 1999; Figueiredo, 1991), were used: 'Valencia' sweet orange (Citrus sinensis L. Osbeck), 'Hamlin' sweet orange (Citrus sinensis L. Osbeck), 'Cleopatra' mandarin (Citrus reshni Hort. ex Tanaka), and 'Sunki' mandarin (Citrus sunki Hort. ex Tanaka). 'Pera' sweet orange was also used as interstock control.

Four month-old rootstocks seedlings produced in $0.075 \mathrm{~L}$ plastic tubes were transplanted to $4.5 \mathrm{~L}$ plastic bags. Pine bark commercial substrate and control release fertilizer previously mixed into substrate (2204-08 at $2 \mathrm{~kg} \mathrm{~m}^{-3}$ ) were used. Daily fertigation with 24-08-16 soluble fertilizers at $1.2 \mathrm{~g} \mathrm{~L}^{-1}$ was initiated 15 days after transplant, and continued until final evaluation. Both rootstocks had initial height of $35 \mathrm{~cm}$.

Interstock budding was done 100 days after rootstock transplant, $12 \mathrm{~cm}$ above the substrate line, when 'Swingle' citrumelo and 'Volkamer' lemon had a stem diameter of $0.69 \mathrm{~cm}$ and $0.64 \mathrm{~cm}$, respectively.
The T-budding method was used with unwrapping of the buds occurring 14 days after budding. Fresh budwood of all interstock cultivars was used. Rootstock looping was applied as a bud eye forcing method. The second growth flush was observed 120 days after budding. The main stems were pruned at a height of $60 \mathrm{~cm}$ above the substrate line to avoid overgrowth and shading.

'Pera' sweet orange budding was performed 210 days after interstock budding, $12 \mathrm{~cm}$ above the interstock/rootstock bud union, with unwrapping of the buds occurring 20 days later. Interstock canopy was pruned just after budding, $15 \mathrm{~cm}$ above interstock/scion bud union. Rootstock looping was maintained at that time. Interstock and rootstock remaining scions were completely eliminated 60 days after second budding, when 'Pera' sweet orange finished first growth flush. Evaluation was finished 100 days after budding with 'Pera' sweet orange.

Experiment was set in $2 \times 5$ factorial scheme (rootstock $\times$ interstock), with 10 treatments in 3 randomized block replications. Experimental unit was comprised of 12 plants, a total of 360 nursery trees. Arc sin $\{\sqrt{ }[(\mathrm{x}+\alpha) / 100]\}$ transformation was applied for data expressed in percent basis. Variance analysis was carried out through ESTAT statistical software and means were compared by Tukey Test $(\alpha=0.05)$.

Data collected included percentage of interstock bud take; interstock height (cm) 60, 90, 120 and 150 days after budding; percentage of dead and dormant bud eyes; scion height $(\mathrm{cm})$ of 'Pera' sweet orange nursery trees; rootstock stem diameter 100 days after budding; fresh and dry matter $(\mathrm{g})$ of scion and root system 100 days after budding (three plants were used per replication and the material was dried at $64^{\circ} \mathrm{C}$ for 72 hours); and root system volume $(\mathrm{mL})$, which was measured according to Bernardi et al. (2000). Time required for complete citrus nursery tree production, and discard percentage of inadequate nursery trees were also measured.

\section{RESULTS AND DISCUSSION}

Interstock bud take percentage was higher in 'Swingle' citrumelo, with $90 \%$ of the bud eyes alive 25 days after interstock, while 'Volkamer' lemon led to a $77 \%$ survival rate (Table 1). 'Pera' sweet orange budded on 'Volkamer' lemon (control) had the lowest bud take percentage, only $50 \%$. However, there were no symptoms of incompatibility between scion and either rootstock until 10 months after interstock budding, or an influence of the interstock on nursery tree growth during experimental evaluations. 
Table 1 - Bud take percentage and height of 'Pera', 'Valencia' and 'Hamlin' sweet oranges and 'Sunki' and 'Cleopatra' mandarins as interstocks budded on 'Swingle' citrumelo and 'Volkamer' lemon 60, 90, 120 and 150 days after budding (DAB).

\begin{tabular}{|c|c|c|c|c|c|c|}
\hline \multicolumn{7}{|c|}{ Interstock } \\
\hline Rootstock & 'Pera' & 'Valencia' & 'Hamlin' & 'Sunki' & 'Cleopatra' & Mean \\
\hline \multicolumn{7}{|c|}{ Interstock bud take } \\
\hline \multicolumn{7}{|c|}{ - } \\
\hline 'Swingle' & 86.11 Аa & $80.56 \mathrm{Aa}$ & $88.89 \mathrm{Aa}$ & $97.22 \mathrm{Aa}$ & $97.22 \mathrm{Aa}$ & $90.00 \mathrm{~A}$ \\
\hline 'Volkamer' & $50.00 \mathrm{Bb}$ & $72.22 \mathrm{Aab}$ & $83.33 \mathrm{Aa}$ & $91.67 \mathrm{Aa}$ & $88.89 \mathrm{Aa}$ & $77.22 \mathrm{~B}$ \\
\hline Mean & $68.06 \mathrm{~b}$ & $76.39 \mathrm{ab}$ & $86.11 \mathrm{ab}$ & $94.45 \mathrm{a}$ & $93.06 \mathrm{ab}$ & \\
\hline \multicolumn{7}{|c|}{ Interstock height } \\
\hline &  & - & $--\mathrm{cm} \mathrm{-.}$ & (5) & - & \\
\hline \multicolumn{7}{|l|}{$60 \mathrm{DAB}$} \\
\hline 'Swingle' & $21.02 \mathrm{Ad}$ & $22.56 \mathrm{Acd}$ & $28.41 \mathrm{Ac}$ & $43.84 \mathrm{Aa}$ & $36.81 \mathrm{Ab}$ & $30.53 \mathrm{~A}$ \\
\hline 'Volkamer' & $17.47 \mathrm{Ac}$ & $26.60 \mathrm{Ab}$ & $22.71 \mathrm{Abc}$ & $37.41 \mathrm{Ba}$ & $26.49 \mathrm{Bb}$ & $26.14 \mathrm{~B}$ \\
\hline Mean & $19.24 \mathrm{c}$ & $24.58 \mathrm{bc}$ & $25.56 \mathrm{bc}$ & 40.62 a & $31.65 \mathrm{~b}$ & \\
\hline \multicolumn{7}{|l|}{$90 \mathrm{DAB}$} \\
\hline 'Swingle' & $32.94 \mathrm{Ac}$ & $37.10 \mathrm{Ac}$ & $43.11 \mathrm{Ac}$ & $80.33 \mathrm{Aa}$ & $62.02 \mathrm{Ab}$ & $51.10 \mathrm{~A}$ \\
\hline 'Volkamer' & $24.99 \mathrm{Bc}$ & $31.79 \mathrm{Bc}$ & $33.39 \mathrm{Bc}$ & $58.68 \mathrm{Ba}$ & $44.24 \mathrm{Bb}$ & $38.62 \mathrm{~B}$ \\
\hline Mean & $28.96 \mathrm{c}$ & $34.44 \mathrm{c}$ & $38.25 \mathrm{c}$ & $69.50 \mathrm{a}$ & $53.13 \mathrm{~b}$ & \\
\hline \multicolumn{7}{|l|}{$120 \mathrm{DAB}$} \\
\hline 'Swingle' & $30.78 \mathrm{Ac}$ & $36.14 \mathrm{Ac}$ & $43.05 \mathrm{Ac}$ & 107.23 Аa & $77.91 \mathrm{Ab}$ & $59.02 \mathrm{~A}$ \\
\hline 'Volkamer' & $20.87 \mathrm{Bc}$ & $29.88 \mathrm{Bc}$ & $34.39 \mathrm{Bc}$ & $75.93 \mathrm{Ba}$ & $56.96 \mathrm{Bb}$ & $43.61 \mathrm{~B}$ \\
\hline Mean & $25.82 \mathrm{c}$ & $33.01 \mathrm{c}$ & $38.72 \mathrm{c}$ & $91.58 \mathrm{a}$ & $67.43 \mathrm{~b}$ & \\
\hline \multicolumn{7}{|l|}{$150 \mathrm{DAB}$} \\
\hline 'Swingle' & $39.43 \mathrm{Ac}$ & $44.97 \mathrm{Ac}$ & $43.27 \mathrm{Ac}$ & $122.56 \mathrm{Aa}$ & $87.88 \mathrm{Ab}$ & $67.62 \mathrm{~A}$ \\
\hline 'Volkamer' & $33.57 \mathrm{Ac}$ & $32.92 \mathrm{Bc}$ & $40.83 \mathrm{Ac}$ & $91.77 \mathrm{Ba}$ & $74.06 \mathrm{Bb}$ & $54.63 \mathrm{~B}$ \\
\hline Mean & $36.5 \mathrm{c}$ & $38.94 \mathrm{c}$ & $42.05 \mathrm{c}$ & $107.16 \mathrm{a}$ & $80.97 \mathrm{~b}$ & \\
\hline
\end{tabular}

Means followed by different capital and lowercase letters, respectively in columns and lines, differ from each other by Tukey's Test $(\alpha=0.05)$.

Citrus incompatibility is usually caused by physiological factors initially characterized by bud union crease and gum release (Agustí, 1999; Pompeu Jr. et al., 1972). Usually symptoms of incompatibility such as scion size reduction will be observed only during grove formation after planting of nursery trees in the field, several years after budding (Castle et al., 1993). Additional symptoms are the death of the root system, rootstocks showing abnormal shooting, and leaf chlorosis. Trees show a reduction in growth and can die after some years. Union between rootstock and scion tissues is deficient, with a lack of tissue union and necrosis, due to tissue rejection and differences in diameter between phloem and xylem vessels (Valero, 1984).

'Swingle' citrumelo plants were taller than 'Volkamer' lemon plants at interstock budding stage, $117.4 \mathrm{~cm}$ and $95.5 \mathrm{~cm}$, respectively (data not shown). 'Swingle' citrumelo also led to the tallest interstocks 60 to 150 days after budding (Table 1). 'Sunki' mandarin was the most vigorous interstock cultivar, fol- lowed by 'Cleopatra' mandarin and the sweet oranges. This fact may be explained by the juvenility of the propagation material (Hartmann et al., 2002), because mandarin budwood was obtained from rootstock seedlings, while sweet orange budwood was obtained from budwood foundation blocks. Different interstocks could induce different vigor and duration for nursery tree production cycle (Cámara et al., 2003).

'Sunki' mandarin interstock led to greater dormant bud eye percentage (36\%) compared to 'Valencia' $(23 \%)$ and 'Pera' sweet orange (22\%) (Table 2). Therefore, there was no influence of rootstock, but only of interstock, on 'Pera' sweet orange bud take percentage. 'Sunki' mandarin is characterized by low polyembriony rate and high percentage of zygotic seedlings recovery, with great number of zygotic seedlings being used as rootstock, and this may affect bud take percentage and scion growth (Soares et al., 1999). Dead bud eye percentage was not influenced by any treatments, with an average rate of $6.7 \%$. Dead bud eye 
Table 2 - Dormant bud eye percentage and scion height and rootstock stem diameter of 'Pera' sweet orange budded on 'Pera', 'Valencia' and 'Hamlin' sweet orange and 'Sunki' and 'Cleopatra' mandarins, on 'Swingle' citrumelo and 'Volkamer' lemon rootstocks, 100 days after budding (DAB).

\begin{tabular}{|c|c|c|c|c|c|c|}
\hline \multicolumn{7}{|c|}{ Interstock } \\
\hline Rootstock & 'Pera' & 'Valencia' & 'Hamlin' & 'Sunki' & 'Cleopatra' & Mean \\
\hline \multicolumn{7}{|c|}{ Dormant budeye of 'Pera' sweet orange } \\
\hline \multicolumn{7}{|c|}{ - } \\
\hline 'Swingle' & $13.89 \mathrm{Ab}$ & $25.00 \mathrm{Aab}$ & $27.78 \mathrm{Aab}$ & $30.56 \mathrm{Aa}$ & $25.00 \mathrm{Aab}$ & $29.26 \mathrm{~A}$ \\
\hline 'Volkamer' & $16.67 \mathrm{Ab}$ & $11.11 \mathrm{Ab}$ & $13.89 \mathrm{Ab}$ & $41.67 \mathrm{Aa}$ & $16.67 \mathrm{Ab}$ & $25.00 \mathrm{~A}$ \\
\hline Mean & $22.68 \mathrm{~b}$ & $22.93 \mathrm{~b}$ & $26.58 \mathrm{ab}$ & $36.78 \mathrm{a}$ & $26.74 \mathrm{ab}$ & \\
\hline \multicolumn{7}{|c|}{ Scion height of 'Pera' sweet orange } \\
\hline & 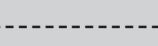 & $-2-0$ & $-\mathrm{cm}--$ & 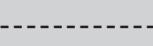 & 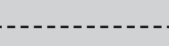 & \\
\hline 'Swingle' & $55.50 \mathrm{Ba}$ & $71.78 \mathrm{Aa}$ & $61.20 \mathrm{Aa}$ & $57.33 \mathrm{Aa}$ & $65.08 \mathrm{Aa}$ & $62.17 \mathrm{~A}$ \\
\hline 'Volkamer' & $77.14 \mathrm{Aa}$ & $61.91 \mathrm{Aa}$ & $70.38 \mathrm{Aa}$ & $59.83 \mathrm{Aa}$ & $64.02 \mathrm{Aa}$ & $66.65 \mathrm{~A}$ \\
\hline Mean & $66.32 \mathrm{a}$ & $66.84 \mathrm{a}$ & $65.78 \mathrm{a}$ & $58.58 \mathrm{a}$ & $64.55 \mathrm{a}$ & \\
\hline \multicolumn{7}{|c|}{ Rootstock stem diameter } \\
\hline & 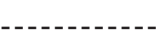 & $-\cdots-1-1$ & $---\mathrm{mm}--$. & 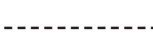 & - - & \\
\hline 'Swingle' & $15.08 \mathrm{Aa}$ & $16.17 \mathrm{Aa}$ & $14.63 \mathrm{Aab}$ & $12.71 \mathrm{Ab}$ & 14.57 Aab & $14.63 \mathrm{~A}$ \\
\hline 'Volkameriano' & $10.91 \mathrm{Ba}$ & $12.63 \mathrm{Ba}$ & $13.31 \mathrm{Aa}$ & $12.05 \mathrm{Aa}$ & $13.19 \mathrm{Aa}$ & $12.42 \mathrm{~B}$ \\
\hline Mean & $12.99 \mathrm{a}$ & $14.39 \mathrm{a}$ & $13.97 \mathrm{a}$ & $12.38 \mathrm{a}$ & $13.87 \mathrm{a}$ & \\
\hline
\end{tabular}

Means followed by different capital and lowercase letters, respectively in columns and lines, differ from each other by Tukey's Test $(\alpha=0.05)$.

could be a result of intrinsic characteristics of the budwood used, or even inadequate budding timing, instead of being influenced by rootstock, as physiological aspects of budwood source plant affect budding in other fruit crops (Araújo \& Castro Neto, 2002).

Plant height of 'Pera' sweet orange was not influenced by interstock or rootstock, with the exception of those plants on 'Pera' sweet orange interstock budded on 'Volkamer' lemon compared to the same combination budded on 'Swingle' citrumelo (Table 2). 'Volkamer' lemon is considered a more vigorous rootstock when compared to others (Pompeu Jr., 1991). In Northeast Brazil, trials involving 'Pera' sweet orange as scion, 'Volkamer' lemon had similar vigor and yield when compared to 'Rangpur' lime and rough lemon (Prudente et al., 2004). 'Swingle' citrumelo stem diameter was superior to 'Volkamer' lemon (Table 2). Actually, 'Swingle' citrumelo is reported as a vigorous rootstock in different citrus regions of the world, inducing large canopies even when compared to 'Volkamer' lemon some years after planting (Agustí, 1999; Castle et al., 1993).

'Sunki' mandarin interstock induced smaller 'Swingle' citrumelo rootstock stem diameter compared to 'Pêra' and 'Valencia' sweet orange interstocks, evidence that interstocks influence trunk diameter differently (Table 2). In Italy, interstocks are used to reduce the trunk diameter at the budding union point, as its enlargement is believed to reduce sap flow rate and, consequently, influence on plant growth and fruit production (Gil-Izquierdo et al., 2004). Therefore, different interstocks may induce different trunk diameter, and thus distinct plant vegetative growth.

'Swingle' citrumelo had the greatest scion and root system fresh and dry matter (Table 3 ). Root system average volume was of $65 \mathrm{~mL}$ being not influenced by treatments. That is an interesting fact as 'Swingle' citrumelo had greater root system dry matter. Therefore, there may be anatomical differences between the root systems of these rootstocks. 'Volkamer' lemon, like 'Rangpur' lime, has a fibrous root system with a large number of feeder roots, while citrumelos are characterized by a denser root system (Wutscher, 1998). In field conditions, 'Volkamer' lemon induces smaller root system influencing on plant growth of 'Tahiti' lime (Neves et al., 2004).

The nursery tree production cycle lasted 17 months from rootstock sowing, 10 months from interstock budding. The typical citrus nursery tree production cycle lasts 10 to 12 months from rootstock sowing in screened nurseries in São Paulo State (Girardi et al., 2005). Although the interstocked nursery tree production cycle is long, this technique is promising because it can lead to reduction in plant size and, consequently, allow for greater orchard density (Castle, 1981; Krezdorn, 1978). 
Table 3 - Scion and root system fresh and dry weight of 'Pera' sweet orange nursery trees budded on 'Pera', 'Valencia' and 'Hamlin' sweet oranges and 'Sunki' and 'Cleopatra' mandarins, on 'Swingle' citrumelo and 'Volkamer' lemon rootstocks, 100 days after budding (DAB).

\begin{tabular}{|c|c|c|c|c|c|c|}
\hline \multicolumn{7}{|c|}{ Interstock } \\
\hline Rootstock & 'Pera' & 'Valencia' & 'Hamlin' & 'Sunki' & 'Cleopatra' & Mean \\
\hline \multicolumn{7}{|c|}{ - Scion fresh weight } \\
\hline \multicolumn{7}{|c|}{ - } \\
\hline 'Swingle' & 127.72 & 124.99 & 152.59 & 147.68 & 148.66 & $140.32 \mathrm{~A}$ \\
\hline 'Volkamer' & 99.59 & 122.10 & 114.69 & 103.51 & 101.30 & $108.24 \mathrm{~B}$ \\
\hline Mean & $113.65 \mathrm{a}$ & $123.54 \mathrm{a}$ & $133.63 \mathrm{a}$ & $125.60 \mathrm{a}$ & $124.98 \mathrm{a}$ & \\
\hline \multicolumn{7}{|c|}{ - Root system fresh weight - } \\
\hline \multicolumn{7}{|c|}{ - } \\
\hline 'Swingle' & 92.14 & 71.56 & 90.80 & 80.72 & 91.85 & $85.41 \mathrm{~A}$ \\
\hline 'Volkamer' & 56.39 & 70.52 & 74.89 & 55.64 & 53.15 & $62.12 \mathrm{~B}$ \\
\hline Mean & $74.26 \mathrm{a}$ & $71.04 \mathrm{a}$ & $82.84 \mathrm{a}$ & $68.18 \mathrm{a}$ & $72.49 \mathrm{a}$ & \\
\hline \multicolumn{7}{|c|}{ - Scion dry weight } \\
\hline \multicolumn{7}{|c|}{ - } \\
\hline 'Swingle' & 49.69 & 47.3 & 57.85 & 56.16 & 57.5 & $53.70 \mathrm{~A}$ \\
\hline 'Volkamer' & 37.70 & 47.15 & 46.18 & 42.00 & 38.61 & $42.32 \mathrm{~B}$ \\
\hline Mean & $43.70 \mathrm{a}$ & $47.22 \mathrm{a}$ & $52.02 \mathrm{a}$ & $49.07 \mathrm{a}$ & $48.05 \mathrm{a}$ & \\
\hline \multicolumn{7}{|c|}{ - Root system dry weight } \\
\hline \multicolumn{7}{|c|}{ - } \\
\hline 'Swingle' & 35.76 & 29.73 & 38.36 & 31.35 & 37.42 & $34.52 \mathrm{~A}$ \\
\hline 'Volkamer' & 22.01 & 29.93 & 31.55 & 23.64 & 21.59 & $25.75 \mathrm{~B}$ \\
\hline Mean & $28.88 \mathrm{a}$ & $29.82 \mathrm{a}$ & $34.95 \mathrm{a}$ & $27.50 \mathrm{a}$ & $29.50 \mathrm{a}$ & \\
\hline
\end{tabular}

Means followed by different capital and lowercase letters, respectively in columns and lines, differ from each other by Tukey's Test $(\alpha=0.05)$.

Right after citrus sudden death disease (CSD) was observed in Sao Paulo and Minas Gerais States in 1999, 'Rangpur' lime started to be replaced as rootstock due to its susceptibility to this disease (Müller et al., 2002). Therefore, 'Pera' sweet orange can be grafted on fewer rootstocks because it is incompatible with 'Volkamer' lemon, Poncirus trifoliate, and its hybrids. Interstocking could lead to greater rootstock diversification for this scion variety especially in CSD affected areas. Considering that 'Rangpur' lime is used as rootstock in almost $80 \%$ of Sao Paulo State groves (Pompeu Jr. et al., 2002), and 'Pera' sweet orange is one of the main scion varieties, rootstock diversification is a high priority action to be taken in setting new groves.

High level of discard plants (35\%) and the double budding operation led to a higher nursery tree cost when compared to usual nursery trees produced in Brazil (Pozzan \& Kanashiro, 2004). Discard is a result of dormant and dead bud eyes, plus nursery trees with inadequate growth 10 months after interstock budding. However, interstocking is a major alternative for citrus nursery production when incompatible scion/ rootstock combinations are desirable. Cost-benefit associated with this kind of nursery tree needs to be analyzed after long-term field experiments. The increase in orchard setting costs could be offset by improved plant protection leading to greater plant longevity.

\section{ACKNOWLEDGEMENTS}

To FAPESP for financial support and scholarship to first author; to CNPq for a research fellowship to the second author; to SaniCitrus Mudas for technical support; to Dr. Jay L. Schell for critical comments.

\section{REFERENCES}

AGUSTÍ, M. Virosis y enfermidades afines. In: AGUSTÍ, M. Citricultura. Madrid: Ediciones Mundi-Prensa, 1999. p.290-291.

ARAÚJO, F.P. de; CASTRO NETO, M.T. Influência de fatores fisiológicos de plantas matrizes e de época do ano no pegamento de diferentes métodos de enxertia do umbuzeiro. Revista Brasileira de Fruticultura, v.24, p.752-755, 2002.

BERNARDI, A.C.C.; CARMELLO, Q.A.C.; CARVALHO, S.A. Development of citrus nursery trees grown in pots in response to NPK fertilization. Scientia Agricola, v.57, p.733-738, 2000. 
BITTERS, W.P.; COLE, D.A.; MCCARTY, C.C. Effect of budding height on yield and tree size of 'Valencia' orange on two rootstock. Proceedings of the International Society of Citriculture, v.1, p.109-110, 1981.

CÁMARA, J.M.; GARCIA-SANCHEZ, F.; NIEVES, M.; CERDA, A. Effect of interstock ('Salustiano' orange) on growth, leaf mineral composition and water relations of one year old citrus under saline conditions. Journal of Horticultural Science \& Biotechnology, v.78, p.161-167, 2003.

CASTLE, W.S. Planting density and tree size control in citrus. Florida Agricultural Experiment Station Journal Series, n.1040, p.3037, 1981.

CASTLE, W.S.; TUCKER, D.P.H; KREZDORN, A.H.; YOUTSEY, C.O. Rootstocks for Florida citrus. 2.ed. Gainesville: University of Florida, 1993. 92p.

FIGUEIREDO, J.O. Variedades copa de valor comercial. In: RODRIGUEZ, O.; VIÉGAS, F.; POMPEU JR., J.; AMARO, A.A. Citricultura brasileira. Campinas: Fundação Cargill, 1991. v.1, p.228-264.

GIL-IZQUIERDO, A.; RIQUELME, M.T.; PORRAS, N.; FERRERES, F. Effect of the rootstock and interstock grafted in lemon tree (Citrus limon (L.) Burm.) on the flavonoid content of lemon juice. Journal of Agricultural and Food Chemistry, v.52, p.324-331, 2004.

GIRARDI, E.A.; MOURÃO FILHO, F.A.A.; GRAF, C.C.D.; OLIC, F.B. Vegetative growth of citrus nursery trees related to the container volume. Fruits, v.59, p.101-105, 2005.

HARTMANN, H.T.; KESTER, D.E.; DAVIES JR., F.T.; GENEVE, R.L. Plant propagation: principles and practices. 7.ed. New Jersey: Prentice Hall, 2002. 880p.

KREZDORN, A.H. Interstocks for tree size control in citrus. Proceedings of the Florida State for Horticultural Society, v.91, p.50-52, 1978.

LLORENTE, S.; ROMOJARO, F.; UREÑA, R.; ALCARAZ, C.F. Influence of intermediate grafting technique on Verna lemon fruit quality. In: INTERNATIONAL COLLOQUIUM FOR THE OPTIMIZATION OF PLANT NUTRITION, 6., Montpellier, 1984. Proceedings. Montpellier: GERDAT, 1984. v.1, p.339-344.

MÜLLER, G.W.; NEGRI, J.D.; AGUILAR-VILDOSO, C.I.; MATTOS JR., D.; POMPEU JR., J.; TEÓFILO SOBRINHO, J.; CARVALHO, S.A.; GIROTTO, L.F.; MACHADO, M.A. Morte súbita dos citros: uma nova doença na citricultura brasileira. Laranja, v.23, p.371$386,2002$.

NEVES, C.S.V.J.; MURATA, I.M.; STENZEL, N.M.C.; MEDINA, C.C.; BORGES, A.V.; OKUMOTO, S.H.; LEE, R.H.C.; KANAI, H.T. Root distribution of rootstocks for 'Tahiti' lime. Scientia Agricola, v.61, p.94-99, 2004.

POMPEU JR, J. Porta-enxertos. In: RODRIGUEZ, O.; VIÉGAS, F.; POMPEU JR., J.; AMARO, A.A. Citricultura brasileira. Campinas: Fundação Cargill, 1991. v.1, p.265-280.
POMPEU JR, J.; DONADIO, L.C.; FIGUEIREDO, J.O. Incompatibilidade entre tangor Murcote e trifoliata. Campinas: Instituto Agronômico de Campinas, 1972. 6p. (Boletim Técnico, 15).

POMPEU JR., J.; LARANJEIRA, F.F.; BLUMER, S. Laranjeiras 'Valência' enxertadas em híbridos de trifoliata. Scientia Agricola, v.59, p.93-97, 2002.

POZZAN, M.; KANASHIRO, M. Custo de muda cítrica em viveiro telado. In: FNP CONSULTORIA \& COMÉRCIO. AGRIANUAL 2004: anuário da agricultura brasileira. São Paulo, 2004. p.250-253.

PRUDENTE, R.M.; SILVA, L.M.S.; CUNHA SOBRINHO, A.P. Comportamento da laranjeira 'Pêra' sobre cinco porta-enxertos em ecossistema de tabuleiros costeiros, Umbaúba-SE. Revista Brasileira de Fruticultura, v.26, p.110-112, 2004.

SAMAD, A.; MCNEIL, D.L.; KHAN, Z. Effect of interstock bridge grafting (M9 dwarfing rootstock and same cultivar cutting) on vegetative growth, reproductive growth and carbohydrate composition of mature apple trees. Scientia Horticulturae, v.79, p.23-38, 1999.

SAMPAIO, V.R. Behavior of 'Valencia' orange trees grafted on Rangpur lime with interstock of Poncirus trifoliata. In: INTERNATIONAL HORTICULTURAL CONGRESS, 23., Firenze, 1990. Abstracts. Bologna: National Research Council, 1990. p.329.

SAMPAIO, V.R. Efeitos de filtros de Poncirus trifoliata e de alturas de enxertia na laranjeira 'Valencia' enxertada em limão 'Cravo'. Scientia Agricola, v.50, p.360-364, 1993.

SCARPARE FILHO, J.A.; KLUGE, R.A.; VICTORIA, R.; TESSARIOLI NETO, J.; JACOMINO, A.P. Behavior of two peach cultivars with 'Januaria' as a Japanese plum interstock. Pesquisa Agropecuária Brasileira, v.35, p.757-765, 2000.

SOARES, W.D.; MOREIRA, C.D.; da CUNHA, M.A.P.; SOBRINHO, A.P.D.; PASSOS, O.S.; MORAIS, L.S. Hybrid vigour on 'Sunki' mandarin. Pesquisa Agropecuária Brasileira, v.34, p.903-909, 1999.

VALERO, J.B.F. Interacciones entre el injerto y el patron em los agrios. Ministerio de Agricultura, pesca y Alimentacion, Madrid, ESPANA, Hojas Divulgadoras, n.9, p.1-20, 1984.

WUTSCHER, H.K. Uso apropriado de las combinaciones injerto/patron en citricos en el tropico. Proceedings of the Interamerican Society of Tropical Horticulture, v.42, p.166-172, 1998.

YONEMOTO, Y.; MATSUMOTO, K.; FURUKAWA, T.; ASAKAWA, M.; OKUDA, H.; TAKAHARA, T. Effects of rootstock and crop load on sap flow rate in branches of 'Shirakawa Satsuma' mandarin (Citrus unshiu Marc.). Scientia Horticulturae, v.102, p.295-300, 2004.

Received September 12, 2005

Accepted December 28, 2005 